\title{
Soil Bulk Density and Porosity Changes due to Ground- based Timber Extraction in the Hyrcanian Forest
}

\author{
Shoukuh SOLTANPOUR, Meghdad JOURGHOLAMI* \\ University of Tehran, Faculty of Natural Resources, Department of Forestry and Forest \\ Economics, Karaj,Iran; mjgholami@ut.ac.ir (*correspondingauthor)
}

\begin{abstract}
Assessment and management of environmental impacts of forest harvesting activities, one of the main reasons is that its importance is increasing day by day. Skidding operations could lead to an increase in detrimental soil disturbance and soil surface compaction that reduced forest soil fertilities. The aim of this study was to investigate and quantify of forest soil compaction following the skidding operations with wheeled cable skidder. This study was carried out in compartment no. 311 and 319 in Gorazbon district in Kheyrud forest in Hyrcanian forest. This study was conducted in a completely randomized factorial design and changes in soil bulk density and porosity with the skidder traffic intensity such as low intensity (less than 3 passes), moderate ( 3 to 7 passes) and very large (more than 7 passes) and two depths of 0-10 and 10-20 cm of soil were measured. The results showed that with the increase of machine traffic, soil bulk density was increased but the largest percentage increase was observed in initial passes (less than 3 times). Soil bulk density at the depth 0-10 and 10-20 cm, was more than the control area by 21.2 and 6.5 percent, respectively. Soil porosity percentage at wheel rut was decreased comparing to the control area and this reduction in the $0-10 \mathrm{~cm}$ depth was greater than $10-20 \mathrm{~cm}$ soil depth. The most of the porosity reduction were occurred in the low intensity traffic and increase in skidder traffic has shown less effect on reducing soil porosity.
\end{abstract}

Keywords: machine traffic, soil compaction, soil bulk density, wheeled skidder

\section{Introduction}

During forest harvesting operations, however, the use of modern machinery and equipment has been accelerated the logging operation, and improved the quality and quantity of wood products and reduced costs. But forest soil was compacted and the natural balance of environment and regeneration would be disrupted. Deforestation and soil degradation begins simultaneously. Soil conservation in forestry and forest management is one of the most important principles that must be continually repeated. Forest owner and engineers have tried to develop techniques that can be used for logging machinery that not to decline soil fertility. Soil compaction, rutting, soil disturbance and displacement, failure of the natural drainage structures, removal of the soil organic matter on skid trails were such as the corrosive effects of the skidding operation (Makineci et al. ,2007; Najafi et al., 2009; Rab, 2004). Soil compaction is a common consequence of the ground-based skidding systems that always occurred in heavy machinery operation (Greacen and Sand, 1980).

The most visible and tangible result of soil compaction is its impact on soil bulk density; however, the intensity of these effects can vary in different situations. Soil bulk density was used as soil compaction index that was a mass of dry soil per unit volume of solid, liquid and gas phase (Froehlich, 1976; Williamson and Neilsen, 2000). Soil compaction and removal of soil surface layer can alter plant root systems and reduce root growths and decrease the soil's ability to supply oxygen, nutrients and water that the plant needs to be survived (Murphy, 2004). Grail (2000) stated that the harvesting operation and use of heavy machinery in the forest, typically by impacting on soil bulk density, soil degradation grains, reduce porosity and permeability capacity of the soil, finally influence on soil structure and soil stability and erosion was thereby caused. Because of skidding machine traffic and wheel rut on soil, reduced soil total porosity, soil particles were closer together and will be strengthen than natural situation (Froehlich, 1980). Soil compaction is reduced the volume of spaces or pores in the soil, especially the size of the pores between the particles, which are the components of the soil affecting gas emissions. During soil compaction, the proportion of macropores was reduced and the ratio of micropores was increased.

Degree and depth of the forest soil compaction due to skidding operations depends on several variables, including soil characteristics: soil texture, soil moisture content at the traffic time (Baris and Camire, 1998; Kozlowski, 1999; Rab, 1999; Senyk and Graigdallie, 1997), soil organic matter, brash mat (Froehlich and McNabb, 1984; Kozlowski, 1999; Wasterlund, 1985), soil structure (Froehlich and McNabb, 1984), parent materials (Brais and Camire, 1988) and particle size distribution (Froehlich 
264

and McNabb, 1984; Wasterlund, 1985), magnitude and nature of the compact force, weight and type of mashine, traffic intensity (Brais and Camire, 1998; Rab, 1996), skid trail conditions: skid trail type (Greacen and Sands, 1980; Rab, 1999; Senyk and Graigdallie, 1997), skid direction (Braise and Camire, 1988; McNabb, 1984) and skidding patterns (Froehlich and McNabb, 1984), forest stand characteristics: density and structure, species composition (Harvey and Brais, 2002; Senyk and Craigdallie, 1997), methods of operation (Carter et al., 1997; Rab, 1999; Harvey and Brais, 2002), training, experience and skill of the equipment operator (Greacen and Sands, 1980; Harvey and Braise, 2002).

The most important factors affecting soil compaction was traffic intensity. Several studies have shown that the most of forest soil compaction has been occurred during first initial passes, and subsequent machine passes on soil will result in diminishing extra compaction degrees (Froehlich, 1978; Hatchell et al., 1997; Steinbrenner, 1995). This first initial passes has been stated that by McDonald et al. (1998) with 3 passes, by Froehlich and McNabb (1984) with 5 machine passes, by Lotfalian et al. (2003) to 5 machine passes, by Naghdi et al. (2007) equal to 6 passes, by Jamshidi et al. (2008) to 6 passes and by Najafi et al. (2009) in 3-7 traffic. Dickerson (1976) studied the soil compaction in the full-tree system on the sandy loam soil and silty clay loam soils of the North Mississippi's. He concluded that after 20 passes of wheeled skidder, soil bulk

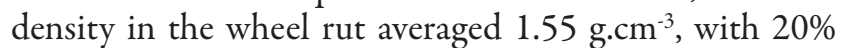
increasing. Also, by increasing the number of passes, soil bulk density was increased, but most of the increase occurred in the initial pass.

The most of the soil compaction occurs in the superficial layers and the bulk density could be reduced by machine traffic as soil depth was increased (Froehlich et al., 1983). The real depth of compaction was differed considering the layers of soil, roots, large rocks and structures of different machine types (Froehlich et al., 1980). Soil compacted layers were often at different depths in the soil. Compaction may be low, medium and deep. Under heavy traffic load, some of the soil was compacted to a depth of $1 \mathrm{~m}$ or more. However, the highest degree of compaction occurred usually the first $30 \mathrm{~cm}$ soil profile depth, which includes the most of the plant roots (Wingate-Hill and Jakobson, 198). Given that forest harvesting operations with skid trail construction, and machines traffic to extract forest products on the trail each year, causing extensive damage to the soil and a wide range of production can be reduced; therefore it is necessary to study the amount of damage to soil characteristics. Among all the forest logging methods, ground skidding systems have the most used and most of the environmental problems and damages were associated with this system. About a third of the forest area was allocated in the skid trails in the forest, and machine and transportation operation were affected a large part of the forest area and irreparable damage to the soil (McMahan et al., 1999;
Rab et al., 2005). The aim of this study was to investigate and quantify the effects of ground skidding systems on forest soils influenced by two factors, intensity of machine traffic and soil depth.

\section{Materials and methods}

\section{The Study Area}

The research was carried out in Compartments 311 and 319 of Gorazbon district, in Kheyrud Educational and Research Forest Station in the Hyrcanian forest region in the north of Iran. The compartments have an altitude range of 1050-1270 m asl, and the forest lies on an southern aspect. Average rainfall ranges from 1150 to 1260 $\mathrm{mm} / \mathrm{year}$, and is heaviest in summer and autumn. The forest stand was uneven aged with average growing stock of 289.1 and $555.2 \mathrm{~m}^{3} / \mathrm{ha}$. This area is dominated by natural forests containing native mixed deciduous tree species including Fagus orientalis Lipsky, Carpinus betulus L., Alnus subcordata, and Quercus castaneifolia. The silvicultural regime is selection based, with harvesting as a combination of group selection and single tree selection. The combination of timber type and topography limits mechanization to the transport function. Felling, limbing, topping, and on-site processing trees are motor-manual (Jourgholami, 2012). The soil of study site is classified as a brown forest soil (Alfisols) and well-drained. The texture of the soil is ranging from silt loam to loamy.

Trees to be removed are felled, limbed and topped motor-manually. Felled trees are bucked and processed with chainsaws into logs, sawn-lumber and pulpwood. The logs with 5-15 meter length are extracted by rubber-tired skidders to the roadside landings. The fuel wood is extracted by mules. Also, in steep terrain that can not be reached by skidders, logs are processed to sawn-lumber and then hauled by mules. An important strategy is to limit traffic on designated skid trails, hence, landings and skid trails were clearly flagged on the ground before harvesting operation. The intension was to require the skidder to stay on the skid trail and winch logs on the trail. Downhill and uphill skidding to the landing are planned without any excavation and the skidding operations are done on natural ground. The extraction distances to the landing area near forest roadside was $350 \mathrm{~m}$. The skid trail slope ranges from 0 to $25 \%$.

\section{Experimental design and data collection}

Felling of marked tree was carried out in March and skidding operation was done in June 2012. At the time of harvesting of site, weather conditions had been dry and these conditions remained more constant during skidding operations. The 4WD Timberjack 450C rubber-tired skidder used in the study is normally an articulated, fourwheel-drive vehicle weighing 10.3 ton $(55 \%$ on the front and $45 \%$ on the rear axle) with engine power of $177 \mathrm{hp}$ $(132 \mathrm{~kW})$ and engine model of 6BTA5.9. It is equipped 
with a blade for light pushing of obstacles and stacking of logs. The skidder was fitted with size 24.5-32 tires inflated to $220 \mathrm{kPa}$ on both front and rear axles, and it had a ground clearance approximately $0.6 \mathrm{~m}$ with overall width of $3.1 \mathrm{~m}$. Timber bunching is carried out by the winch installed in the rear part of the skidder from the stump to the skidder and one end of the dragged round wood is in touch with ground. In the study areas, the average logged volumes in each pass were $3.5 \mathrm{~m}^{3}$ ( 1 and 3 logs respectively).

A sampling transect were selected at different slope gradients along the designated skid trail for bulk density measurements (Fig. 1). Organic horizons were removed from the soil surface prior to density measurements, so that depth readings were referenced to the mineral soil surface. In order to ensure that the measurements were made in the same place after certain number of passes, we have implanted the painted sticks in the center of skid trails. The painted sticks indicated the centers of the experimental skid trails at the skid trial, in order that the machines would follow the same tracks at subsequent passes. The different levels of compaction were applied by varying the levels of machine traffic: 0 (undisturbed), $<3,3-7$ and $>7$ machine passes. A pass implies a drive back and forth the selected trail. Also, prior to any skidding operations and after machine passes, bulk density and soil porosity were measured at the $0-10$ and $10-20 \mathrm{~cm}$ soil profile depths in wheel rut and control sample point adjacent skid trail. The soil sample cores were obtained from the layers of the mineral soil using a thin walled steel cylinder, $40 \mathrm{~mm}$ long and $56 \mathrm{~mm}$ in diameter, driven into the soil by a hammerdriven device. After extracting the steel cylinder from the soil with minimal disturbance to the contents, the soil cores were trimmed flush with the cylinder end and extruded into a plastic bag for transporting to the labora-

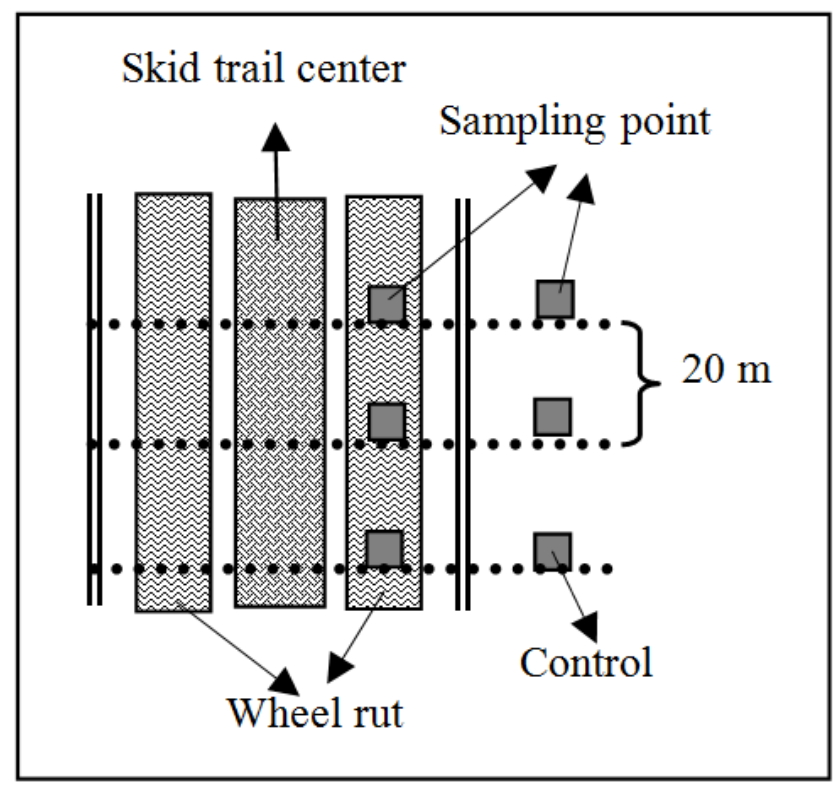

Fig. 1. Sampling scheme for the soil bulk density and total porosity in skid trail tory. Samples were weighed on the day they were collected and again after oven drying at $105^{\circ} \mathrm{C}$ for $24 \mathrm{~h}$ to determine water content and bulk density.

\section{Statistical analysis}

The experimental design was a factorial arrangement of treatments conducted in a completely randomized design. The general linear modeling (GLM) also applied to relate bulk density and soil porosity to machine passes and depth in relation to the skid trails. Post-hoc comparison of means was performed using Duncan's multiple designs to meanbased grouping with a 95\% confidence level. Analysis of variance of the data was conducted in SPSS (release 15.0) to identify differences between bulk density values of four slope gradients in skid trails. Treatment effects were considered significant if $p<0.05$. Soil bulk density before and after skidder operations was compared using independent samples t-test. Also, one-way ANOVA was performed.

\section{Results and discussion}

\section{Soil bulk density}

Tab. 1 shows the analysis of the soil bulk density data as influenced by machine passes and soil depth for the cable skidder. Results showed that machine passes and soil depth were significant variables $(p<0.05)$ and the interaction effect of machine passes $\times$ soil depth was insignificant.

Average pre-harvest bulk densities for two soil depth classes, $0-10$ and $10-20 \mathrm{~cm}$ were $0.85 \mathrm{~g} \mathrm{~cm}^{-3}$ and $1.07 \mathrm{~g}$ $\mathrm{cm}^{-3}$, respectively (Fig. 2). Soil bulk density increased by $21.2 \%$ in $0-10 \mathrm{~cm}$ depth that reached to $1.03 \mathrm{~g} \mathrm{~cm}^{-3}$ and by $6.5 \%$ in $10-20 \mathrm{~cm}$ that reached to $1.14 \mathrm{~g} \mathrm{~cm}^{-3}$ after machines passes. After machine passes, bulk density increased in soil profile depth under the skid trails, but the major increases occurred in the top of the soil profile at $0-10 \mathrm{~cm}$.

The bulk density in the $0-10 \mathrm{~cm}$ of soil $\left(0.96 \mathrm{~g} \mathrm{~cm}^{-3}\right)$ increased by $13.3 \%$ after less than 3 pass, $19.1 \%$ after 3-7 passes and 19.6\% after higher than 7 passes. Soil bulk density after skidding operation for control, less than 3 pass, 3-7 passes and higher than 7 passes levels were 0.96, 1.09, 1.14 and $1.15 \mathrm{~g} \mathrm{~cm}^{-3}$, respectively. Bulk density after $>7$ machine passes showed the highest value in comparison with other machine passes by Duncan's test (Fig. 3). The machine passes have a statistically significant effects on bulk density $(p<0.05)$ before and after skidding operation, but the bulk density have not any significant increasing among three machine pass classes.

Tab. 1. Analysis of variance (ANOVA) for the effect of number of machine passes

\begin{tabular}{cccccc}
\hline Source & Sum of Squares & $\mathrm{df}$ & Mean Square & $F$-value & $P$-value \\
\hline $\mathrm{NP}$ & 0.436 & 3 & 0.154 & 6.71 & 0.000 \\
$\mathrm{SD}$ & 0.243 & 1 & 0.243 & 10.57 & 0.002 \\
$\mathrm{NP} \times \mathrm{SD}$ & 0.079 & 3 & 0.026 & 1.15 & 0.334 \\
\hline
\end{tabular}

$(\mathrm{NP})$ and soil depth (SD) on bulk density 


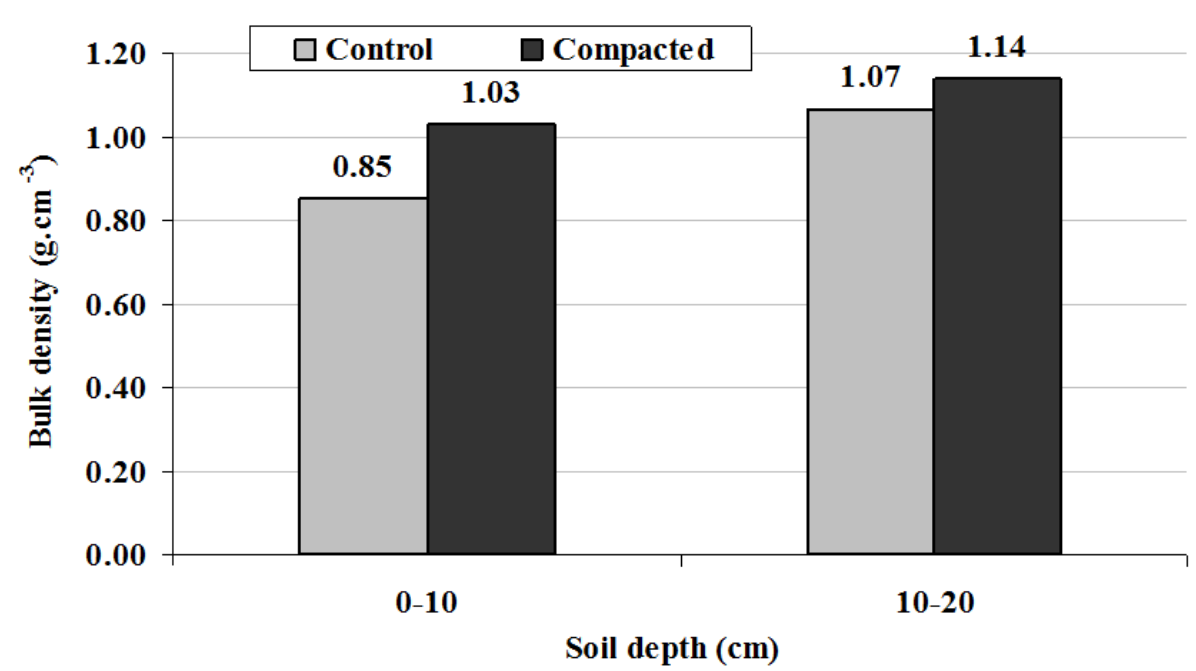

Fig. 2. Comparison of bulk density in both control and compacted tail in the soil depth

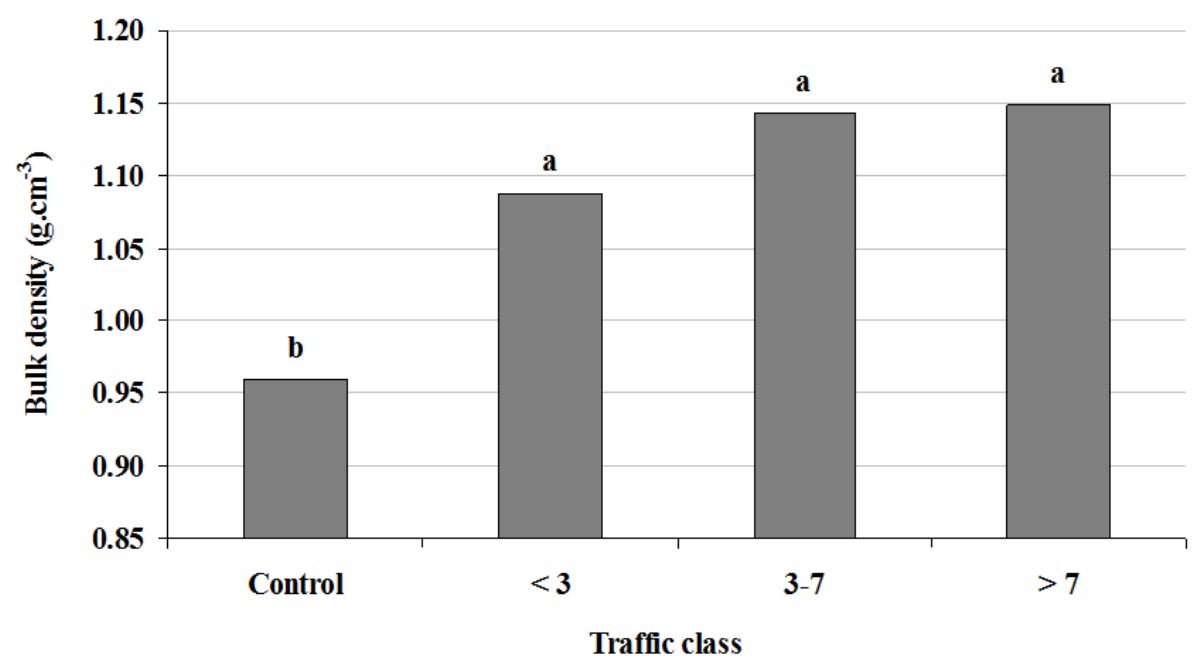

Fig. 3. Average of the bulk density in $\mathrm{g} \mathrm{cm}^{-3}$ and its relative changes before and after skidding in each of the traffic classes using Duncan's test (b). Different letters within each slope treatments shows significant differences $(p<0.05)$

Soil porosity

Tab. 2 shows the analyses of the soil bulk density data as influenced by machine pass and soil depth after skidding operation. Results showed that machine pass and soil depth have a significant effects on soil porosity and the interaction machine pass $\times$ soil depth have not any significant effects on soil porosity $(p<0.05)$.

Average pre-harvest soil porosities for two soil depth classes, $0-10$ and $10-20 \mathrm{~cm}$ were $58.2 \%$ and $52.34 \%$, respectively (Fig. 4). Soil porosity decreased by $11 \%$ in $0-10$ $\mathrm{cm}$ depth that reached to $51.51 \%$ and by $8 \%$ in $10-20 \mathrm{~cm}$ that reached to $48.05 \%$ after machines passes. After machine passes, soil porosity decreased in soil profile depth under the skid trails, but the major decreases occurred in the top of the soil profile at $0-10 \mathrm{~cm}$. As Fig. 4 shows, soil porosity in the control area was less than the soil porosity in compacted trail, and at $0-10 \mathrm{~cm}$ depth greater than the $10-20 \mathrm{~cm}$. Soil porosity decreases with increasing depth, but this value is lower than the initial depth. The lowest amount of porosity in the $10-20 \mathrm{~cm}$ depth at wheel rut as $48.05 \%$ is achieved.

The soil porosity in the $0-10 \mathrm{~cm}$ of soil $(55.27 \%) \mathrm{de}-$ creased by $9 \%$ after less than 3 pass, $14 \%$ after 3-7 passes and $16.6 \%$ after higher than 7 passes. Soil porosity after skidding operation for control plots, less than 3 pass, 3-7 passes and higher than 7 passes levels were 55.27, 50.28, 47.51 and $46.08 \%$, respectively. Soil porosity after $>7 \mathrm{ma}-$ chine passes showed the lowest value in comparison with other machine passes by Duncan's test (Fig. 5). The ma-

Tab. 2. Analysis of variance (ANOVA) for the effect of number of machine passes (NP) and soil depth (SD) on soil porosity

\begin{tabular}{cccccc}
\hline Source & Sum of Squares & $\mathrm{df}$ & Mean Square & $F$-value & $P$-value \\
\hline NP & 968.039 & 3 & 328.68 & 7.034 & 0.000 \\
SD & 239.501 & 1 & 239.501 & 5.126 & 0.027 \\
NP $\times$ & 53.18 & 3 & 17.727 & 0.379 & 0.768 \\
SD & & & & \\
\hline
\end{tabular}




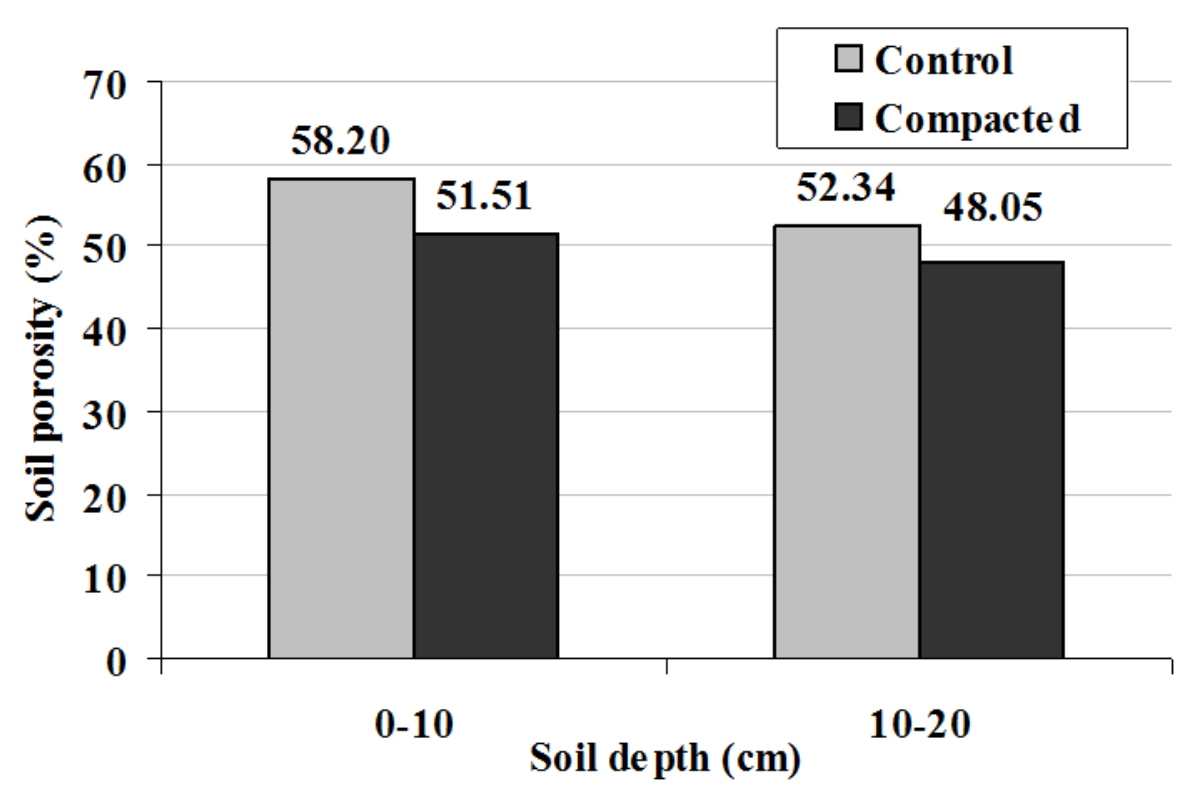

Fig. 4. Comparison of soil porosity in both control and compacted tail in the soil depth

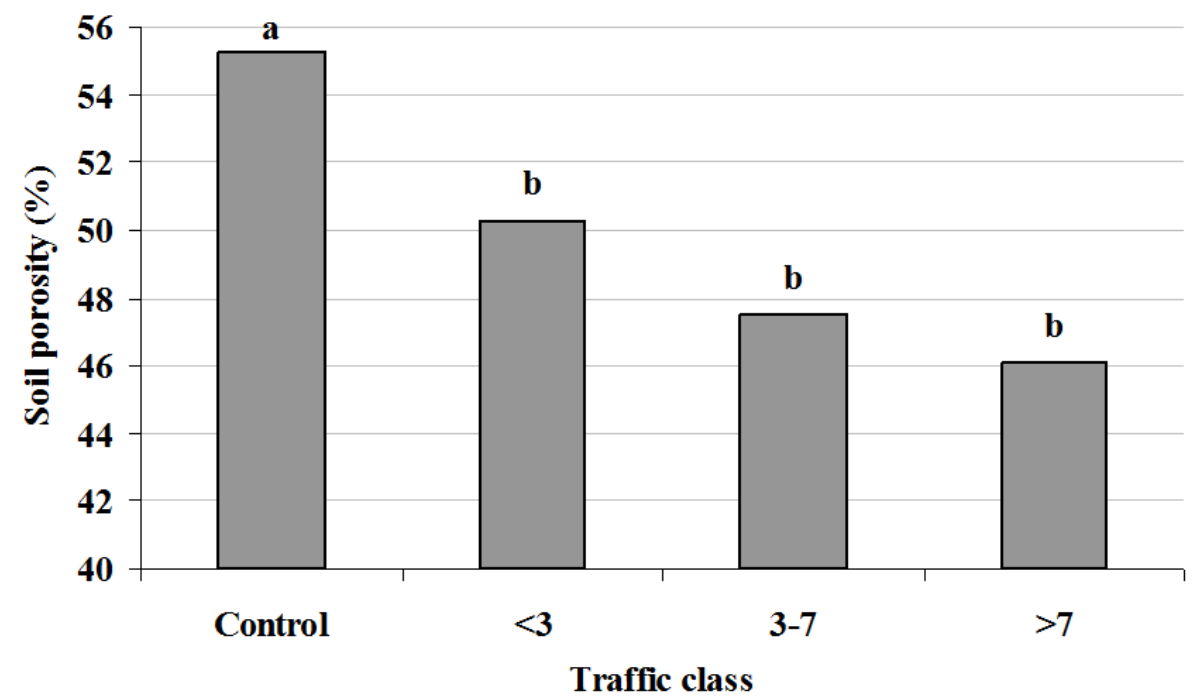

Fig. 5. Average of the soil porosity in $\mathrm{g} \mathrm{cm}^{-3}$ and its relative changes before and after skidding in each of the traffic classes using Duncan's test (b). Different letters within each slope treatments shows significant differences $(p<0.05)$

chine passes have a statistically significant effects on soil porosity $(p<0.05)$ before and after skidding operation among three machine pass classes.

According to the obtained results, the soil bulk density increased with increasing soil depth. One reason for this phenomenon can be introduced by soil organic matter, such as soil organic matter in surface horizons high, decreases rapidly with increasing depth that resulting in the soil bulk density increased. Froehlich and Mcnabb (1981) and Kozlowski (1999) proved that reduce soil organic matter functionality increases soil compaction. Result shows that average bulk density significantly increased after wheeled skidder operations. However, in different machine of increased bulk densities were statistically different. Results of majority of studies were consistent with our result (Froehlich, 1978; Froehlich and McNabb, 1984; Hatchell et al., 1997; Lotfalian et al., 2003; Jamshidi et al., 2008; Steinbrenner, 1995; Najafi et al., 2009). Each stress applied at the soil surface is always transmitted three dimensionally and causes not only soil compaction but also shear effects. Result shows that bulk density significantly increased as machine pass increased. The numerous literatures have studied the impacts of the frequency of vehicle passes on soil compaction. These studies show that most compaction occurs during the first few passes of a machine and subsequent machine passes increased the soil compaction at a lesser extent until there is little or no more compaction associated with a machine pass. A possible explanation for this could be: once this initial compaction is complete, further compaction is resisted by the increasing 
268

soil strength and is therefore considerably slower. Also, the bearing capacity of the soil (maximum load without soil structure failure) grows with increasing bulk density. In this way the superficial layer is protected against further compaction when traffic is continued (Ampoorter $e t$ al., 2007).

Results show that average pre-harvest bulk densities significantly increased as soil profile depth increased. In other hand, the values of the native soil bulk density mostly depend on quantity of organic matter, and as with increase of depth, organic matter is rapidly decreased, and the bulk density increased in subsoil. In the upper soil, biological activity (roots and animals) can act to reduce resistance and soil bulk density while at lower depths soil texture, gravel content and structure may increase soil resistance and soil bulk density. For the pre-harvest soil bulk density samples, bulk density increases with depth similar to other studies (Adams and Froehlich, 1984; Greacen and Sands, 1980).

Generally, compaction was slightly more pronounced at depth; substantially the subsoil layer $(0-10 \mathrm{~cm})$ appeared more dence. In this study there was not only compaction at two depths but also with increasing compaction by depth accordance to other studies (Froehlich, 1978; Greacen and Sands 1980; Hatchell, 1970; SteinBrenner, 1995). A strong increase in bulk density is most distinct in the upper $20 \mathrm{~cm}$ of the soil, since the exerted pressure is maximal at the soil surface and declines with increasing depth as the total pressure is spread out over an enlarging area (Ampoorter et al., 2007; Brais and Camire, 1998). Thus, an increase generally occurs especially in the upper soil layers (Greacen and Sands, 1980). Results show that deeper in the soil profile, differences between control and the treatments in four slope gradient became smaller.

We can only speculate why this is occurring. Compaction effect is most distinct in the upper $20 \mathrm{~cm}$ of the soil, since the exerted pressure is maximal at the soil surface and declines with increasing depth as the total pressure is spread out over an enlarging area. Thus, an increase generally occurs especially in the upper soil layers (Carter and McDonald, 1997). Results are expressed in relation to soil porosity show that the largest percentage decrease in soil porosity at a depth of $10-0 \mathrm{~cm}$ and greatly reduce machine traffic has occurred. Ampoorter et al. (2007) stated that soil compaction reduce soil macropores volume and has a significant effect on the reduction of gas and air movement between atmosphere and soil.

\section{Conclusions}

Forest soils with high organic-matter, low bulk density, high porosity and low strength are very susceptible to soil compaction and shear effects. According to our findings, we have to conclude that the most compaction occurred after the initial few passes and reducing the number of trips made over the same trail has not any effect for reduc- ing soil compaction. Hence, even one pass is already sufficient to induce a strong increase in bulk density. Also, slope gradients on trails should be as low as possible, particularly when vehicles are traveling loaded. Severe compaction of soil adversely affects the growth of plants by a combination of physical soil changes and plant physiological dysfunctions. One strategy to limit soil disturbances is to avoid traffic whenever the water content approaches the limit of liquidity, or even exceeds it. Skidding operations should be planned when soil conditions are dry so as to minimize rutting, but if skidding must be done under wet conditions, the operations should be stopped when machine traffic creates deep ruts. The machine traffic should be limit on skid trails. Traffic trails should be developed for forest sites in order to concentrate most forest operations to compacted trails. Preplanning of skid trails and directional felling will improve skidding efficiency, increase safety, and reduce ground disturbance. The impact from the felling of large tree is another source of compaction but this aspect has not been studied in this forest. In Hyrcanian forest which was managed by uneven-aged method, all trees aren't felled in harvesting period, then the strengthening effects and damages of the roots persist and growth losses due to root damage will occur.

\section{References}

Adams PW, Froehlich HA (1984). Compaction of forest soils, USDA Pacific Northwest Extension Publication. PNW 217 a13 p.

Ampoorter E, Goris R, Cornelis WM, Verheyen K (2007). Impact of mechanized logging on compaction status of sandy forest soils. For Ecol Manage 241:162-174.

Brais S, Camiré C (1998). Soil compaction induced by careful logging in the claybelt region of northwestern Quebec (Canada). Can J Soil Sci 78:197-206.

Carter EA, Aust WM, Burger JA (2007). Soil strength of select soil disturbance classes on a wet pine flat in South Carolina. For Ecol Manage 247:131-139.

Carter EA, McDonald TP (1997). Interaction among machine traffic, soil physical properties and loblolly Pine root proliferation in a piedmont soil. Proceedings of the Ninth Biennial Southern Silvicultural Research conference, Clemson, SC, Feb. 25-27 p.

Dikerson BP (1976). Soil compaction after tree-length skidding in northern Mississippi. Soil Sci Soc Am J 40:965-966.

Froehlich HA, McNabb DH (1984). Minimizing soil compaction in Pacific Northwest forests, 159-192 p. In: Forest Soils and Treatment Impacts. Proc. of the 6th North American Forest Soils Conf., E.L. Stone, Ed. Univ. of Tennessee, Knoxville, TN.

Froehlich HA (1976). Soil compaction from logging equipment: effects on growth of young ponderosa pine. J Soil Water Con 34:276-278.

Froehlich HA, Miles DW, Robbins RW (1985). Soil bulk den- 
sity recovery on compacted skid trails in central Idaho. Soil Sci Soc Am J 49:1015-1017.

Froehlich HA (1978). Soil compaction from low ground-pressure, torsion-suspension logging vehicles on three forest soils. Res. Paper 36, Oregon State Univ., Forest Research Lab. 12 p.

Froehlich HA, Azevedo J, Cafferata P, Lynse D (1980). Predicting soil compaction on forested land. Final project Report, Coop Agremeent No. 228. USDA Forest Serv. Equip. Devel. Cent. Missoula, Mt. 120 p.

Grail DF (2000). Effect of extensive forest management on soil productivity. For Ecol Manage 138:167-185.

Greacen EL, Sands R (1980). A review of compaction of forest soils. Aust J Soil Res 18:163-189.

Han HS, Page-Dumroese D, S-Khan D, Tirocke J (2006). Effect of slash, machine passes, and soil wetness on soil strength in a cut-to-length harvesting. Int J For Eng 17(2):11-24.

Harvey B, Braise S (2002). Effects of mechanized careful logging on natural regeneration and vegetation compaction in the southeastern Canadian boreal forest. Can J For Res 32:233-246.

Hatchell GE (1970). Soil compaction and loosening treatment affect loblolly pine growth in pots. USDA for. Serv Res Pap, $9 \mathrm{p}$.

Hatchell GE, Ralston CW, Foil RR (1997). Soil disturbances in logging. J Forestry 68:772-775.

Jamshidi R, Jaeger D, Raafatnia N, Tabari M (2008). Influence of two ground-based skidding systems on soil compaction under different slope and gradient conditions. Int J For Eng 19(1):9-16.

Jourgholami M (2012). Small-scale timber harvesting; mule logging in Hyrcanian Forest. Small-scale Forestry 11(2):255262.

Kozlowski TT (1999). Soil compaction and growth of woody plants. Scan J For Res 14:596-619.

Makineci E, Demir M, Yilmaz E (2007). Long-term harvesting effects on skid road in a fir (Abies bornmulleriana Mattf) plantation forest. Build Environ 42:1538-1543.

McDonald T, Carter E, Taylor S, Torbert J (1988). Relationship between site disturbance and forest harvesting equipment traffic, 85-92 p. In: Whiffen GA HJ-H, and Hubbard WC (Eds.). Proc of the $2^{\text {nd }}$ Southern Forestry GIS Conf, Oct. 2829, Athens.

McMahon S (1999). Accuracy of two ground survey methods for assessing site disturbance. Int J For Eng 6(2):27-33.

Murphy G, Firth JG, Skinner MF (2004). Long-term impacts of forest harvesting related soil disturbance on log product yields and economic potential in a New Zealand forest. Silva Fenn 38(3):279-289.
Naghdi R, Raafatnia R, Sobhany H, Jalali G, Hosseini M (2007). Evaluation of tree length and assortment logging methods with respect to residual damage and productivity in Caspian forest (north of Iran). Reigning Ukrainsky Lisotehnichny University 296-302 p.

Najafi A, Solgi A, Sadeghi SHR (2009). Effect of ground skidding and skid trail slope on soil disturbance. Soil Till Res 103:165-169.

Rab MA (1996). Soil physical and hydrological properties following logging and slash burning in the Eucalyptus regnans forest in southeastern Australia. For Ecol Manage 84:159176.

Rab MA (1999). Measures and operating standards for assessing Montreal process soil sustainability indicators with reference to Victorian Central Highlands forest, southeastern Australia. For Ecol Manage 117:53-73.

Rab MA (2004). Recovery of soil physical properties from compaction and soil profile disturbance caused by logging of native forest in Victorian Central Highlands, Australia. For Ecol Manage 191:329-340.

Rab MA, Bradshaw FJ, Campbell RG, Murphy S (2005). Review of factors affecting disturbance, compaction and trafficability of soils with particular to timber harvesting in the forests of south-west Western Australia, Consultants Report to Department of Conservation and Land Management, Western Australia, Sustainable Forest Management Series, SFM Technical Report No. 2, 146 p.

Senyk J, Craigdallie D (1997). Ground-based wet weather yarding operations in coastal British Columbia: Effects on soil properties and seedling growth. Canadian Forest Service, Pacific Forestry Center, Information Rep BC-X-372. 32 p.

Steinbrenner EC, Gessel SP (1955). The effect of tractor logging on physical properties of some forest soils in southwestern Washington. Soil Sci America Proc 19:372-376.

Wasterlund I (1985). Compaction of till soils and growth tests with Norway spruce and Scot pine. For Ecol Manage 11:171-189.

Williamson JR, Neilsen WA (2000). The influence of forest site on rate and extent of soil compaction and profile disturbance of skid trails during ground-based harvesting. Can J For Res 30:1196-1205.

Wingate-Hill R, Jakobsen BF (1982). Increased mechanization and soil damage in forests- a review. New Zealand J Forest Sci 12(2):380-393. 